\title{
A growth cline in encrusting benthos along a latitudinal gradient within Antarctic waters
}

\author{
David K. A. Barnes ${ }^{1, *}$, Rodney Arnold ${ }^{2}$ \\ ${ }^{1}$ Department of Zoology and Animal Ecology, University College Cork, Lee Maltings, Cork, Ireland \\ ${ }^{2}$ British Antarctic Survey, High Cross, Madingley Road, Cambridge CB3 0ET, England
}

\begin{abstract}
Growth and mortality of 3 species (Inversiula nutrix, Celleporella bougainvillei, Fenestrulina rugula) of encrusting bryozoans were examined from 5 Antarctic localities, along a latitudinal gradient. Typically, growth in marine invertebrates is, for ecological equivalents, slower or much slower in cold seas than warm waters. Contrary to the general trend, growth rates of 3 bryozoans were found to accelerate with increasing latitude in Antarctic waters. Population age structure also showed a dramatic change across the 5 study sites (from 54 to $68^{\circ} \mathrm{S}$ ) through hugely increased mortality with increasing latitude. Reduction in inter-specific competition is theorised as explaining higher growth rates. Increased levels of ice scour are probably responsible for the differential mortality.
\end{abstract}

KEY WORDS: Benthos $\cdot$ Antarctic $\cdot$ Growth $\cdot$ Mortality $\cdot$ Disturbance $\cdot$ Cline

Resale or republication not permitted without written consent of the publisher

\section{INTRODUCTION}

The tempo of growth in marine invertebrates is, for ecological equivalents (species occupying similar niches), typically slower in cold seas than in warm waters (Everson 1977, Berkman 1990, Arntz et al. 1994, Brey et al. 1995, Peck et al. 1997). Of the polar marine invertebrates studied to date, most have been found to have considerably lowered basal metabolism, reproductive effort and growth rates (the latter determined by counting of growth-check lines). Growth measurements have found large within- and between-taxa variance in polar invertebrates. For example, bryozoan and mollusc growth in polar species has been found to vary from comparable to $\geq 10 \times$ slower than in warmwater species (Barnes 1995, Pearse et al. 1991 respectively). A few sponge and ascidian species have, however, growth rates comparable or faster than equivalent warm-water species (Dayton et al. 1974, Rauschert 1991). The growth-check lines on some brachipods suggest they may grow very slowly in Antarctic waters (Brey et al. 1995). The recent discov-

*E-mail: dkab@ucc.ie ery of a greater than annual frequency of growthcheck line production in brachiopod shells (Peck \& Brey 1998) suggests that even some of the earlier estimates may be inflated due to previous assumptions of annual periodicity of such marks.

Whilst slower polar growth has long been considered a valid generalisation, the principal cause of this generalisation has been unclear and debated. The brevity of food (phytoplankton) availability (Clarke 1988) and low temperature per se (Pearse et al. 1991) have been suggested as possible explanations for poor polar secondary productivity. Although certain suspension feeders have been found to feed and grow for most of or throughout the year, the levels of available food are low (Barnes 1995, Barnes \& Clarke 1995), while temperature has been suggested as being important, in particular with respect to larval development times (Bosch et al. 1987, Pearse et al. 1991). The low variation of temperature within the Southern Ocean would suggest that temperature is unlikely to influence any comparison of life characteristics within polar waters.

Growth-rate variation with latitude, for any given species, has not been compared within cold (polar) waters, with the exception of 1 preliminary study. Barnes \& Arnold (1999) showed that certain shallow- 
water species were abundant and common at certain localities along the Scotia Arc and that there was a suggestion of higher growth at an Antarctic Peninsula site than further north. Both growth and population age structure had simply been determined by counting faint growth-check lines. Such rings in these species had previously been determined as annual in periodicity. We compared populations of 3 species of bryozoans between the localities of South Georgia $\left(54^{\circ} \mathrm{S}\right)$, Signy Island $\left(60.5^{\circ} \mathrm{S}\right)$, Dobrowolski Island $\left(63^{\circ} \mathrm{S}\right)$, Galindez Island $\left(65.5^{\circ} \mathrm{S}\right)$ and Adelaide Island $\left(68^{\circ} \mathrm{S}\right)$. The purpose of the growth and mortality measurements was to clarify the following: (1) Do growth rates of the same species vary between sites and are the level and trend of between-site variation similar in each of the 3 study species? (2) Is there evidence that mortality rates of the same species vary between sites and are the level and trend of between-site variation similar in each of the 3 study species? (3) Do any observed (between-site) differences in growth and/or mortality follow a latitudinal trend?

\section{METHODS}

The sites were chosen to span the latitudes encompassed by the Southern Ocean, and are shown in Fig. 1. The northernmost limit of the Southern Ocean, determined by the Polar Frontal Zone, varies with season and longitude (Dell 1972). The study island of South Georgia $\left(54^{\circ} \mathrm{S}\right)$ is at this extreme whilst the southern-most study locality, Adelaide Island $\left(68^{\circ} \mathrm{S}\right)$, is nearly at the opposite extreme. Although there is ocean beyond $68^{\circ} \mathrm{S}$, it is mainly covered with sheet ice, and thus not only difficult to sample but also under a very different environmental regime than our study sites. The sites between these 2 extremes were other islands along the Scotia Arc. Only the small and exposed South Sandwich islands lie between South Georgia and Signy Island, but for logistic reasons these could not be sampled. All sites are inside the Polar Frontal Zone, and thus are subject to similarly narrow fluctuations and absolute sea-temperature regimes (Arntz et al. 1994). Between Signy Island $\left(60.5^{\circ} \mathrm{S}\right)$ and McMurdo sound $\left(77.5^{\circ} \mathrm{S}\right)$ there is a $0.1^{\circ} \mathrm{C}$ difference in winter sea temperature and a $2.0^{\circ} \mathrm{C}$ difference in summer sea temperature. At the time of collection, the site with the warmest sea temperature was South Georgia $\left(1^{\circ} \mathrm{C}\right)$ and the coldest site was Adelaide Island $\left(0.5^{\circ} \mathrm{C}\right)$. The duration of sea-ice has not been measured at most sites to date, but typically increases with increasing latitude along the sites (Barnes 1999a).

There are few encrusting species common to all 5 of the study localities, at a standard depth, and abundant enough for sampling. Three cheilostomatid bryozoan species, Inversiula nutrix, Celleporella bougainvillei and Fenestrulina rugula, were the most common and abundant overall (see Barnes \& Clarke 1998, Barnes \& Arnold 1999). Of the study species, I. nutrix occurred at all 5 study localities, whilst $C$. bougainvillei and $F$. rugula were present at only 4 of the 5 . A random sample of about 50 rocks was collected from $6 \mathrm{~m}$ depth along the shore at each of the study sites using SCUBA in the Austral summer of 1997/1998. The rocks varied in size from a few $\mathrm{cm}^{2}$ to a few hundred $\mathrm{cm}^{2}$ surface area. All colonies of each of the 3 study species were counted and measured.

The mean proportion of each age class (within localities) was assessed by averaging the number of 2, 3, 4 and 5 yr class colonies for every hundred 1 yr old colonies counted. The measurements recorded for each colony were the number of (annual) growthcheck lines, the surface area $\left(\mathrm{mm}^{2}\right)$ and the size in number of modular units or zooids. The size (in area and zooid number) at each age was measured for each colony. That is, for a $3 \mathrm{yr}$ old colony, size was measured at its 1 yr band, 2 yr band and 3 yr band. Surface area was measured by tracing round colonies and measuring the 2-dimensional area using digitising imageanalysis equipment. The number of zooids per colony was actually counted by eye, through a dissecting microscope.

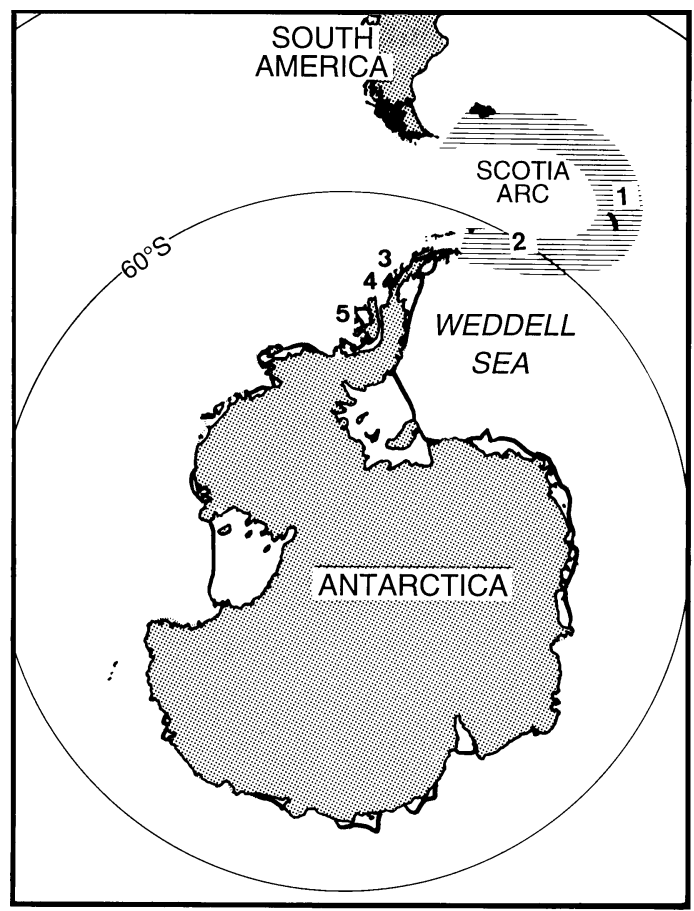

Fig. 1. Positions of study localities (1 to 5) relative to the continents of South America, Antarctica and the Scotia Arc mountain chain. 1: South Georgia; 2: Signy Island; 3: Dobrowolski Island; 4: Galindez Island; 5: Adelaide Island 
Table 1. Inversiula nutrix, Celleporella bougainvillei and Fenestrulina rugula. Colony size (means $+\mathrm{SE}$ ) as a function of latitude and year. Sample sizes varied from 100 (I. nutrix at all sites, Year 1) to 4 (I. nutrix at $54^{\circ} \mathrm{S}$, Year 4$)$ : all $(\log )$ sample sizes are given in Fig. 3 (= no. of colonies). nd = no data or $<3$ samples

\begin{tabular}{|c|c|c|c|c|}
\hline \multirow[t]{2}{*}{ Latitude } & \multicolumn{4}{|c|}{ Mean colony size $\left(\right.$ area $\mathrm{mm}^{-2}$ ) } \\
\hline & Year 1 & Year 2 & Year 3 & Year 4 \\
\hline \multicolumn{5}{|l|}{ I. nutrix } \\
\hline $54^{\circ} \mathrm{S}$ (S. Georgia) & $28.0(3.5)$ & $73.5(5.7)$ & $127.9(10.4)$ & $262.5(43.9)$ \\
\hline $60.5^{\circ} \mathrm{S}$ (Signy Island) & $77.1(6.2)$ & $192(18.9)$ & $339(74.3)$ & nd \\
\hline $63.5^{\circ} \mathrm{S}$ (Dobrowolski Island) & $89.0(6.0)$ & $210.3(13.2)$ & $418.5(55.1)$ & nd \\
\hline $65.5^{\circ} \mathrm{S}$ (Galindez Island) & $98.6(5.8)$ & $233.4(9.9)$ & $449.2(43.6)$ & nd \\
\hline $68^{\circ} \mathrm{S}$ (Adelaide Island) & $109.0(6.5)$ & $253.3(12.9)$ & nd & nd \\
\hline \multicolumn{5}{|l|}{ C. bougainvillei } \\
\hline $60.5^{\circ} \mathrm{S}$ & $23.4(1.8)$ & $80.6(3.9)$ & $155.4(8.1)$ & $226.7(14.1)$ \\
\hline $65.5^{\circ} \mathrm{S}$ & $35.5(2.1)$ & $112.8(4.7)$ & $239.2(13.0)$ & nd \\
\hline $68^{\circ} \mathrm{S}$ & $40.0(2.2)$ & $133.4(6.5)$ & nd & nd \\
\hline \multicolumn{5}{|l|}{ F. rugula } \\
\hline $60.5^{\circ} \mathrm{S}$ & $47.9(2.5)$ & $115.6(5.0)$ & nd & nd \\
\hline $68^{\circ} \mathrm{S}$ & $80.3(3.7)$ & $170.8(8.8)$ & $340(36.2)$ & nd \\
\hline
\end{tabular}

The populations of all 3 species at all localities at which they occurred were dominated by young individuals (Table 1, Fig. 3). The most common age class was $\leq 1 \mathrm{yr}$, with older classes becoming progressively less represented with increasing age. The greatest number of growth-check lines (= oldest colony) on any colony of Inversiula nutrix at South Georgia was 5 (= 5 yr old). The maximum number of check lines on I. nutrix progressively decreased southwards to just 1 at Adelaide Island (Fig. 3). The slope of the fitted line (in Fig. 3a) suggests a mortality rate of $\sim 70 \% \mathrm{yr}^{-1}$ at South Georgia, increasing to $\sim 99 \% \mathrm{yr}^{-1}$ at Adelaide Island. Scars on previous colonies which had been completely removed from rock surfaces were evident on many substratum samples.

\section{RESULTS}

The size-at-age (= growth rate) of colonies of each of the study species showed variability within and between each study locality. The size-at-age values for any given age class overlapped between consecutive localities (latitudes), but values at the highest latitude site did not overlap with those at the lowest site. The high significance (Kruskal-Wallis all $H>43$, all $\mathrm{p}<0.001$ ) of size-at-age values of Inversiula nutrix, Celleporella bougainvillei and Fenestrulina rugula between localities, however, showed the comparative unimportance of within-site variation. All 3 study species showed a similar pattern; colony sizeat-age was lowest at the location with lowest latitude (South Georgia for I. nutrix, Signy Island for C. bougainvillei and F. rugula) and highest at Adelaide Island (the location at the highest latitude: Table 1). The greatest difference in size-at-age values (for colonies of any of the 3 study species) between 2 localities of consecutive latitude was at South Georgia and Signy Island. Here also was the greatest difference in latitude span of any consecutive study sites. The size-at-age differences between site (and, by implication, latitude) were greatest in $I$. nutrix, in which mean colony size was $4 \times$ larger at Adelaide Island than at South Georgia island (Table 1). At the most southerly location, Adelaide Island, 1 yr old colonies were the size of $3 \mathrm{yr}$ old colonies at South Georgia. This species showed a clear trend of increasing age with increasing latitude along the Scotia Arc (Fig. 2).
The age-structure patterns of Celleporella bougainvillei (Fig. 3b) and Fenestrulina rugula were lower than those of I. nutrix along the Scotia Arc, with each having minimum mortality rates of $\sim 70 \% \mathrm{yr}^{-1}$ (at Signy Island) and maximum rates of $\sim 90 \% \mathrm{yr}^{-1}$ (at Adelaide Island). For equivalent localities (latitudes) the mortality rates of $C$. bougainvillei and F. rugula were $\sim 10 \%$ lower than those of $I$. nutrix, e.g. 70,69 and $76 \%$ at Signy Island respectively.

Where the nature of any damage to colonies could be ascertained, it was either crushing of the dorsal side ( $\sim 80 \%$ of cases), scraping of the dorsal side $(\sim 18 \%$ of cases) or breakage of the proximal margin, i.e. the growing edge ( $2 \%$ of cases). Parts of colonies were

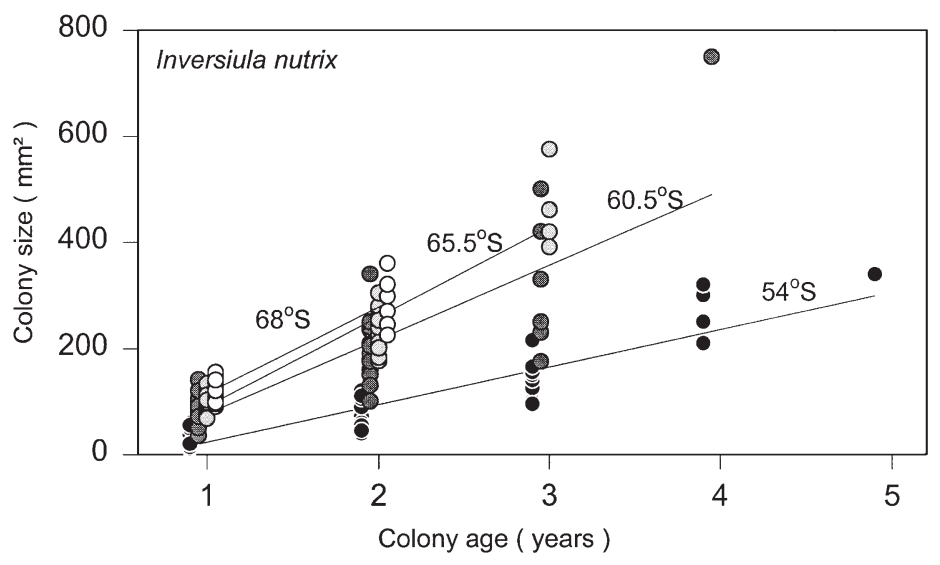

Fig. 2. Growth of the bryozoan Inversiula nutrix with age and latitude. Symbols and regressions (all significant at $p<0.001$ ) are: $\bullet$ South Georgia Island, $y=-47.8+70.8 x, F=284 ; 0$ Signy Island, $y=-63.8$ $+140 x, F=89.9 ; \circ$ Galindez Island $y=-78.1+169 x, F=261$; O Adelaide Island, $y=-48+163 x, F=141.9$ 


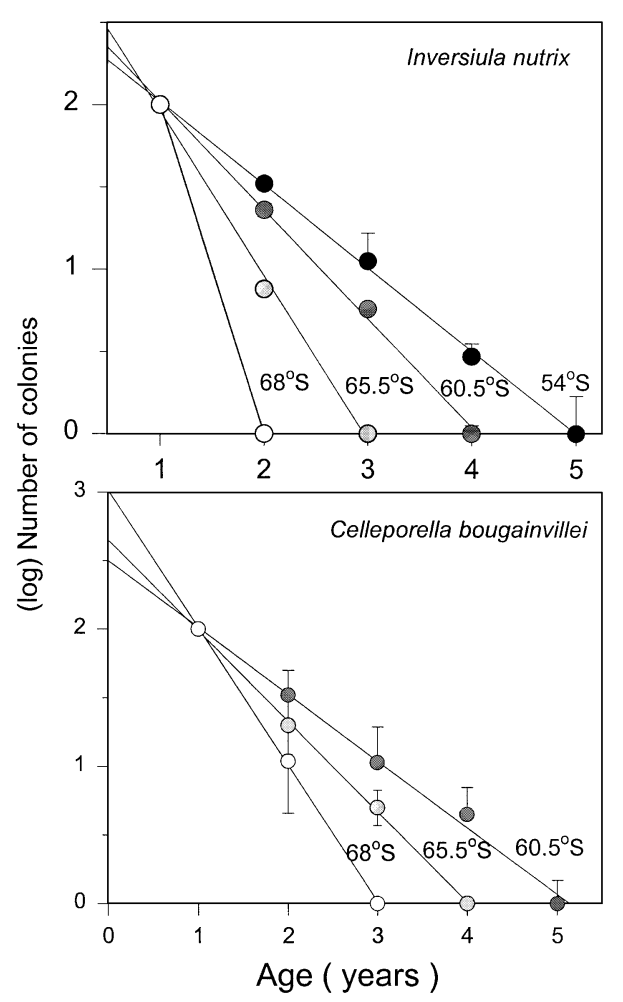

Fig. 3. Number of colonies with age (mortality) and latitude. Data are presented as mean and standard error. The sites are South $(\bullet)$, Signy Island (O); Galindez Island (O) and Adelaide Island (O). The $1 \mathrm{yr}$ age point overlaps for all sites

completely removed by the forces causing the crushing or scraping. Many colonies showed signs of partial mortality and recovery from structural damage. Judgement of the age and growth performance of such colonies was problematical. Correlation of partial mortality rates with age and complete mortality rates would, therefore, incur high levels of error and were not attempted.

\section{DISCUSSION}

Bryozoans are modular colonial organisms (formed of repeating units or zooids) that are exclusively aquatic and mostly marine. They are a particularly suitable group for examining global ecological patterns as they are sessile and 1 of the few taxa abundant and easily accessible on rocky shores at any latitude. The slight differences in the growth and mortality of the 3 species examined here (Inversiula nutrix, Celleporella bougainvillei and Fenestrulina rugula) may have structural explanations, as their zooids differ in size and degree of calcification (see Hayward 1995). As with most animals, measurement of growth in bryozoans is not without certain problems and assump- tions. Here, growth rate of colonies was averaged across year-groups and, as such, masks a variety of subtleties which may have considerable influence on the growth of individual colonies. Amongst such subtleties are position of colony on substrata (local flow regime: see Cancino \& Hughes 1987), genotype (Bayer \& Todd 1996) and shrinkage from mechanical or predation damage (Stanwell-Smith \& Barnes 1997).

Certain bryozoan genera (e.g. Celleporella) and even some species (e.g. C. hyalina) span huge ranges in latitude (Hayward \& Ryland 1999). The existence of such cosmopolitan taxa should not only facilitate growth-rate comparisons of ecologically equivalent species, but also enable comparisons of the same actual species. Compared to the (annual) growth of temperate species, the growth rate of polar bryozoans has been found to range from comparable to more than 1 order of magnitude slower. However, rates seem to be comparable during the actual (shorter) period of growth (Barnes 1995). Such a finding supports the idea of a reduced tempo of growth of polar benthos through food limitation (Clarke 1988), despite the recent findings of a greater than believed duration of nano-phytoplankton (ciliates and flagellates) abundance and suspension-feeding activity (Barnes \& Clarke 1995). Neither ideas on temperature or food-supply limitation have effectively been tested within the range of conditions encountered in polar environments or using the same species. The field data obtained here, whilst not representing a controlled experiment, do, for the first time, compare populations of the same species at different latitudes within a polar environment. The findings support a previous hypothesis (Barnes \& Arnold 1999) that, contrary to the general (polar invertebrate) trend, growth rates increase (for the bryozoans studied at least) with increasing latitude in Antarctic waters.

\section{Why are the findings here so different from the traditional view?}

There are a number of possible explanations for growth not only not decreasing but actually increasing in the study species. First, the trend described here might only be true for encrusting rock dwellers or even just encrusting colonial rock dwellers. The mechanism (decreased inter-specific competition) proposed to explain our findings would only influence animals of such nature (see next paragraph). There is some supporting evidence for this. The few non-rock-dwelling species that have been compared between 2 differing latitudes (within the Southern Ocean) show no evidence of increased growth (Ralph \& Maxwell 1977, cf. Stockton 1984, Barnes 1999b). Second, the growth trend found in the present study depends on growth- 
check lines being produced on a strictly annual basis. This has long been assumed for a variety of taxa, e.g. bivalve molluscs, bryozoans and brachiopods (see Lutz \& Rhoads 1980, Winston 1983, Brey et al. 1995). Whilst this is likely, and has been established for 2 of the study species at 1 of the localities (Signy Island: see Barnes 1996), it was not established separately at each of the study sites. Furthermore, on other species, Barnes (1995) demonstrated a sub-annual frequency of growth-check production (on an erect bryozoan) whilst Peck \& Brey (1998) demonstrated a super-annual frequency (on a brachiopod). If growth-checks at South Georgia were produced super-annually, the latitudinal trend, whilst still present, would not be as striking. Third, the traditional view (see Clarke 1988) is based on inference rather than on direct measurements. Although it seems intuitively reasonable that growth in polar waters is reduced, this need not necessarily rule out a differing pattern within cold waters.

\section{Why should growth increase towards the pole?}

Food availability is unlikely to be a causative factor of a positive growth trend, as bryozoan growth has previously been found to correlate with the duration rather than the magnitude of phytoplankton abundance (Barnes 1995). The duration of phytoplankton availability could only decrease (by virtue of reduced sun hours and longer sea-ice duration) further south. We suggest that differential levels of competition may, however, be responsible. All 3 study species are broadly r-selective, and are easily overgrown by most other bryozoans (Barnes \& Rothery 1996). The proportion of space occupied on rocks decreases significantly (Kruskal-Wallis, $H=29.3$, p < 0.01) with increasing latitude (Fig. 4a). Thus, the weakly competitive study species were less likely to encounter a spatial competitor with increasing latitude. Although the number of bryozoan species occurring on rock substrata increases with increasing latitude (Barnes \& Arnold 1999), it was found in this study that they become much less numerous and the probability of inter-specific encounters and overgrowth decreases significantly $\left(\mathrm{r}^{2}=0.858, \mathrm{p}<\right.$ 0.001 ) from 54 to $68^{\circ} \mathrm{S}$ (Fig. $4 \mathrm{~b}$ ). Whilst colonies experience reduced inter-specific competition, they are involved in greater levels of intra-specific competition. The latter is, however, much less damaging than the former to the size of colonies (particularly in r-selective species), as intra-specific competition rarely involves overgrowth or protracted 'fights' (Barnes \& Rothery 1996, Barnes \& Clarke 1998). That is, weak overgrowth competitors are more able to persist (and grow) with increasing latitude as the hindrance of competition is reduced.
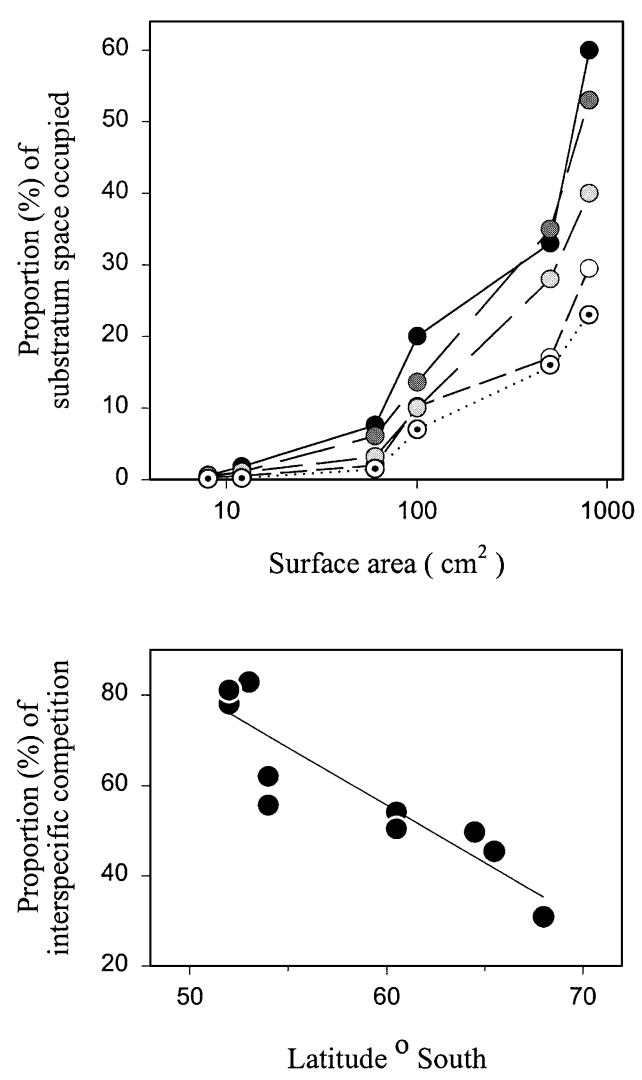

Fig. 4. (a) Various bryozoans and polychaetes. Proportion of space occupied on rocky substrata with substratum surface area. Space occupied refers to all faunal colonisation of primary space (mostly bryozoans). Data from (and for species lists see) Barnes \& Rothery (1996), Barnes \& Arnold (1999) and Barnes (in press). The symbols are Falkland Islands (๑), South Georgia (O), Signy Island (O), Galindez Island (O) and Adelaide Island $(\odot)$. (b) Proportion of inter-specific competition (cf. intra-specific) with latitude south. Data from Barnes (in press)

\section{Why should mortality increase with latitude?}

The oldest colony (of Inversiula nutrix) at South Georgia was 5 yr old, but age in this species decreased with increasing latitude to $1 \mathrm{yr}$ old at Adelaide Island (see Fig. 3a). This striking increase in mortality is probably due to the increase in probability and intensity of ice scour with increasing latitude. Severe or total mortality of macro-benthos has often been observed in the wake of iceberg groundings (Peck \& Bullough 1993, Gutt et al. 1996, Barnes 1999a). That rocks are scoured so regularly means that high Antarctic shore benthos is very young and assemblages are permanently in a state of colonisation and change. A number of important ecological points result from this. Fauna encrusting rocks appear to have different strategic lifestyles than most Antarctic benthos. Typically, Antarctic marine invertebrates are characterised by $K$-strategy 
lifestyles (Clarke 1979). In direct contrast to this, bryozoan (and probably other encrusting taxa) species with r-strategy characteristics became more numerous with increasing latitude in the study assemblages (Barnes \& Arnold 1999, present study). Less space was occupied on substrata with increasing latitude. Biological competition must, therefore, become less important and, as observed in the present study, fewer interspecific interactions and overgrowth occur.

Interspecific encounters are important as they impair growth of a bryozoan colony in a number of different ways. First, potential growth energy can be diverted to form defensive, offensive and sexual structures (Buss 1980, Barnes \& Rothery 1996, Barnes \& Clarke 1998). Second, growth may cease along the line of contact, zooids become distorted or reduced, and parts or all of the colony overgrown. Third, feeding currents may be disturbed or even polluted by the competitor, such that feeding efficiency can be seriously reduced (Buss 1980, McKinney 1992). Thus, reduced levels of inter-specific spatial competition with increasing latitude (within polar waters) seem a plausible explanation for the changes in growth rates observed in the species studied here. If competition causes the observed trend in increased growth, the very different nature and mode of existence of other polar shore dwellers may mean that a similar reversal in growth trend in other taxa does not occur. Interference competition undoubtedly has some influence in alteration of growth for some species, but whether it is the main factor behind the cline reported here remains to be proven.

Acknowledgements. The authors would like to thank the drawing office of the British Antarctic Survey for production of Fig. 1. We would also like to thank the other divers involved in collection of material.

\section{LITERATURE CITED}

Arntz WE, Brey T, Gallardo VA (1994) Antarctic zoobenthos. Oceanogr Mar Biol Annu Rev 32:251-303

Barnes DKA (1995) Seasonal and annual growth in erect species of Antarctic bryozoans. J Exp Mar Biol Ecol 188: 181-198

Barnes DKA (1996) Low levels of colonisation in Antarctica: the role of bryozoans in early community development. In: Gordon DP, Smith AM, Grant-Mackie JA (eds) Bryozoans in space and time. Proceedings of the International Bryozoology Association 10th conference, 30 Jan-3 Feb 1995, Wellington. National Institute for Water and Atmospheric Research, Wellington, NZ, p 19-28

Barnes DKA (1999a) The influence of ice on polar benthos. J Mar Biol Assoc UK 79:401-407

Barnes DKA (1999b) Do life patterns differ between two Scotia Arc localities? A preliminary investigation of three erect Antarctic bryozoan species. Antarct Sci 11:275-282

Barnes DKA (in press) Diversity, recruitment and competition on island shores at south-polar localities compared with lower latitudes; encrusting community examples. Hydrobiologia
Barnes DKA, Arnold RJ (1999) Possible latitudinal clines in Antarctic intertidal and subtidal zone communities encrusting ephemeral hard substrata. J Biogeogr 26:207-213

Barnes DKA, Clarke A (1995) Seasonality of feeding activity in polar suspension feeders. Polar Biol 15:335-340

Barnes DKA, Clarke A (1998) The biology of an assemblage dominant; the encrusting bryozoan Fenestrulina. Invertebr Zool 117:331-340

Barnes DKA, Rothery P (1996) Competition in encrusting Antarctic bryozoan assemblages: outcomes influences and implications. J Exp Mar Biol Ecol 196:267-275

Bayer MM, Todd CD (1996) The effect of polypide regression and other parameters on colony growth in the cheilostomate Electra pilosa (L.) In: Gordon DP, Smith AM, GrantMackie JA (eds) Bryozoans in space and time. Proceedings of the International Bryozoology Association 10th conference. National Institute for Water and Atmospheric Research, Wellington, NZ, p 29-38

Berkman PA (1990) The population biology of the Antarctic scallop Adamussium colbecki (Smith 1902) at New Harbour, Ross Sea. In: Kerry KR, Hempel G (eds) Antarctic ecosystems: ecological change and conservation. SpringerVerlag, Berlin, p 281-288

Bosch I, Beauchamp KA, Steele ME, Pearse JS (1987) Development, metamorphosis and seasonal abundance of embryos and larvae of the Antarctic sea urchin Sterechinus neumayeri. Biol Bull 173:126-135

Brey T, Peck LS, Gutt J, Hain S, Arntz WE (1995) Population dynamics of Magellania fragilis, a brachiopod dominating a mixed bottom macro-benthic assemblage on the Antarctic shelf. J Exp Mar Biol Ecol 95:857-869

Buss LW (1980) Bryozoan overgrowth interactions - the interdependence of competition for space and food. Nature 281:475-477

Cancino JM, Hughes RN (1987) The effect of water flow on growth and reproduction of Celleporella hyalina (L.) (Bryozoa: Cheilostomata). J Exp Mar Biol Ecol 112: 109-130

Clarke A (1979) On living in cold water: $K$-strategies in Antarctic benthos. Mar Biol 55:111-119

Clarke A (1988) Seasonality in the Antarctic marine ecosystem. Comp Biochem Physiol 90:461-473

Dayton PK, Robilliard GA, Paine RT, Dayton LB (1974) Biological accommodation in the benthic community at McMurdo Sound, Antarctica. Ecol Monogr 44:105-128

Dell RK (1972) Antarctic benthos. Adv Mar Biol 10:1-216

Everson I (1977) Antarctic marine secondary production and the phenomenon of cold adaptation. Phil Trans R Soc Lond Ser B 279:55-66

Gutt J, Starmans A, Dieckmann G (1996) Impact of iceberg scouring on polar benthic habitats. Mar Ecol Prog Ser 137: $311-316$

Hayward PJ (1995) Antarctic cheilostomatous bryozoa. Oxford University Press, Oxford

Hayward PJ, Ryland JS (1999) Cheilostomatous Bryozoa. Part 2. Hippothooidea-Celleporidea. Field Stud 10:93-95

Lutz RA, Rhoads DC (1980) Growth patterns within the molluscan shell: an overview. In: Rhoads DC, Lutz RA (eds) Skeletal growth of aquatic organisms. Plenum Press, New York, p 203-254

McKinney FK (1992) Competitive interactions between related clades: evolutionary implications of overgrowth interactions between encrusting cyclostome and cheilostome bryozoans. Mar Biol 114:645-652

Pearse JS, McClintock JB, Bosch I (1991) Reproduction in Antarctic benthic marine invertebrates: tempos, modes and timing. Am Zool 31:65-80 
Peck LS, Brey T (1998) Bomb signals and growth bands in Antarctic brachiopods. Nature 380:207-208

Peck LS, Bullough LW (1993) Growth and population structure in the infaunal bivalve Yoldia eightsi in relation to iceberg activity at Signy Island, Antarctica. Mar Biol 117: 235-241

Peck LS, Brockington S, Brey T (1997) Growth and metabolism in the Antarctic brachiopod Liothyrella uva. Phil Trans R Soc Lond Ser B 352:851-858

Ralph R, Maxwell JHG (1977) Growth of two Antarctic lamellibranchs: Adamussium colbecki and Laternula elliptica. Mar Biol 42:171-175

Rauschert M (1991) Ergebnisse der faunistischen Arbeiten

Editorial responsibility: Otto Kinne (Editor),

Oldendorf/Luhe, Germany im Benthal von King George Island (Südshetlandinseln, Antarktis). Ber Polarforsch 76:1-75

Stanwell-Smith D, Barnes DKA (1997) Benthic community development in Antarctica: recruitment and growth on settlement panels at Signy Island. J Exp Mar Biol Ecol 212: 61-79

Stockton WL (1984) The biology and ecology of the epifaunal scallop Adamussium colbecki on the west side of McMurdo Sound, Antarctica. Mar Biol 78:171-178

Winston JE (1983) Patterns of growth, reproduction and mortality in bryozoans from the Ross Sea, Antarctica. Bull Mar Sci 33:688-702

Submitted: April 3, 2000; Accepted: August 9, 2000

Proofs received from author(s): December 18, 2000 